\title{
Results Regaring Yield Elements Obtained at Different Densities at Certain Soybean Varieties
}

\author{
Raluca REZI ${ }^{12 *}$, Ioan HAȘ ${ }^{12}$, Eugen MUREŞANU ${ }^{1}$ \\ ${ }^{1}$ Agricultural Research \& Development Station, Turda, Romania \\ ${ }^{2}$ University of Agricultural Sciences and Veterinary Medicine Cluj Napoca, Romania \\ * corresponding author: ralucutza_dana@yahoo.com
}

Bulletin USAMV series Agriculture 72(1)/2015

Print ISSN 1843-5246; Electronic ISSN 1843-5386

DOI 10.15835/buasvmcn-agr: 11160

\begin{abstract}
In general, aside from the soybean variety and adequate fertility, different row spacing and density are a major agronomic factors that significantly influence yield potential.

Soybean plants are influenced by the changes in plant population such as different densities namely the competition. Previous research reached these issues from various aspects, however, there is a lack of information regarding how interplant competition affects the yield components or how Romanian varieties of soybean respond to different plant density environments.The objective of this study was to determine the density effects on soybean yield and yield components.
\end{abstract}

Keywords: density, grain yield, morphological characteristics, soybean varieties

\section{INTRODUCTION}

Soybean (Glycine max L.) is a species of legume native to Eastern Asia. Among the legumes, the soybean, is classified as an oilseed, is pre-eminent for its high protein content as well as its high oil content (Perkins, 1995).

The optimum plant density with proper geometry of planting is dependent on variety, its growth habit and agro-climatic conditions (Bilal Ahmad et al, 2009). The increase of plant population reduce yield of individual plants but increases yield per unit of area (RA Ball et al, 2000).

To meet the diversity of ecological conditions found in Transylvania Plain, A.R.D.S. Turda has a wide range of early and very early soybean varieties and the soybean varieties created at A.R.D.S. Turda meet all the features and characteristics needed to achieve the aims of the Breeding Program such as high potential production, high insertion of the basal pods, resistance to lodging, shattering, bacterial blight, downy-mildew, ensures suitable conditions for mechanized harvesting and remarkable qualitative traits, high protein and oil content (Muresanu, 2003, 2011).

\section{MATERIALS AND METHODS}

In the study were included nine early and very early soybean varieties created at Agricultural Research and Development Station Turda and four foreign soybean varieties (Tabel 1).

This research was carried out as factorial experiment based on randomized blocks design with two replications during growing season of 2012 at Agricultural Research and Development Station Turda.

At the end of growth season, 10 plants were selected from each plot randomly and measured yield and morphological characteristics such as: plant height, height of the first basal pod, number 
of branches per plant, number of pod per plant, number of grain per plant, grains weight per plant, thousand grain weight (TGW). After the extraction of 10 plants randomly all plants were harvested.

\section{RESULTS AND DISCUSSION}

The different densities have influenced the response of seed yield and yield components at both the Romanian and foreign soybean varieties. Soybean yield elements obtained at different plant

Tab. 1. The soybean varieties used in the study

\begin{tabular}{ccc}
\hline No. & Variety & Source \\
\hline 1 & Diamant & ARDS Turda \\
\hline 2 & Perla & ARDS Turda \\
\hline 3 & Safir & ARDS Turda \\
\hline 4 & Eugen & ARDS Turda \\
\hline 5 & Onix & ARDS Turda \\
\hline 6 & Felix & ARDS Turda \\
\hline 7 & Darina TD & ARDS Turda \\
\hline 8 & Cristina TD & ARDS Turda \\
\hline 9 & Mălina TD & ARDS Turda \\
\hline 10 & Dekabig & S.U.A \\
\hline 11 & Asgrow & S.U.A \\
\hline 12 & Condor & Novi Sad SERBIA \\
\hline 13 & Balkan & Novi Sad SERBIA \\
\hline
\end{tabular}

density were determined by the yield elements and in this case we focus on the: plant height, number of branches per plant, grains weight per plant and also on the yield.

\section{Yield elements}

\section{Plant height}

The study showed that in the case of plant height there were semnificant differences at the D3 (600 000 seeds/ha) and D4 (750 000 seeds/ha) densities and also at the $25 \mathrm{~cm}$ distance between rows. (Tabel 2) We can notice some genotypes with a high plant height such as: Safir $(92 \mathrm{~cm})$, Onix (92cm), Condor $(89 \mathrm{~cm})$. (Tabel 3)

Number of branches per plant

In the case of number of branches per plant was also observed the very significantly difference between densities, the most positive difference was notice at the D3 density (600 000 seeds/ ha) with $9,9 \%$ more then the average number of branches per plant and the $25 \mathrm{~cm}$ distance between rows. (Tabel 4) Varieties like Perla and Felix with a average number of branches of 61 and Eugen with a average of 67 were notice in the study. (Tabel 5)

Grains weight per plant

The study showed that in the case of grains weight per plant the positive difference was at the D3 (600 000 seeds/ha) with 5,5 per cent more then the average weight and also at the $25 \mathrm{~cm}$

Tab. 2. Influence of density and distance between rows of plant height at the soybean varieties studied (Turda, 2012)

\begin{tabular}{|c|c|c|c|c|c|}
\hline Source of variance & $\begin{array}{l}\text { Plant height } \\
(\mathrm{cm})\end{array}$ & Check & $\%$ & Difference & Significance \\
\hline \multicolumn{6}{|l|}{ Density } \\
\hline $\begin{array}{c}\text { D1 } \\
300000 \text { seeds /ha }\end{array}$ & 78 & 80 & 97,6 & $-1,90$ & 000 \\
\hline $\begin{array}{c}\text { D2 } \\
450000 \text { seeds } / \mathrm{ha}\end{array}$ & 80 & 80 & 99,6 & $-0,33$ & 0 \\
\hline $\begin{array}{c}\text { D3 } \\
600000 \text { seeds } / \mathrm{ha}\end{array}$ & 81 & 80 & 101,4 & 1,13 & $* * *$ \\
\hline $\begin{array}{c}\text { D4 } \\
750000 \text { seeds } / \mathrm{ha}\end{array}$ & 81 & 80 & 101,4 & 1,10 & *** \\
\hline $\begin{array}{ll}\text { DL p 5\% } & 0,27 \\
\text { DL p 1\% } & 0,37 \\
\text { DL p 0,1\% } & 0,48 \\
\end{array}$ & & & & & \\
\hline \multicolumn{6}{|l|}{ Distance between rows } \\
\hline $50 \mathrm{~cm}$ & 78 & 80 & 97,7 & $-1,87$ & 000 \\
\hline $25 \mathrm{~cm}$ & 82 & 80 & 102,3 & 1,87 & $* * *$ \\
\hline $\begin{array}{ll}\text { DL p 5\% } & 0,19 \\
\text { DL p 1\% } & 0,26 \\
\text { DL p 0,1\% } & 0,34\end{array}$ & & & & & \\
\hline
\end{tabular}


distance between rows (Tabel 6). We can notice some genotypes with a high grain weight such as: Eugen, Felix and Asgrow (Tabel 7).

The different densities have influenced the response of seed yield and yield components at both the Romanian and foreign soybean varieties.
Soybean yield elements obtained at different plant density were determined by the plant height, height of the first basal pod, number of branches per plant, number of pod per plant, number of grain per plant, grains weight per plant, thousand grain weight. Results indicated that the soybean

Tab. 3. Plant height at the soybean varieties studied (Turda, 2012)

\begin{tabular}{ccccccc}
\hline No. & Variety & Average $(\mathrm{cm})$ & Check & $\%$ & Difference & Significance \\
\hline 1 & Diamant & 74 & 80 & 92,6 & $-5,92$ & 000 \\
\hline 2 & Perla & 82 & 80 & 102,4 & 1,92 & $* *$ \\
\hline 3 & Safir & 92 & 80 & 114,2 & 11,42 & $* * *$ \\
\hline 4 & Eugen & 81 & 80 & 100,7 & 0,55 & $*$ \\
\hline 5 & Onix & 92 & 80 & 114,2 & 11,42 & $* * *$ \\
\hline 6 & Felix & 81 & 80 & 101,9 & 1,55 & $* *$ \\
\hline 7 & Darina TD & 73 & 80 & 92,0 & $-6,45$ & 000 \\
\hline 8 & Cristina TD & 84 & 80 & 104,9 & 3,92 & $* *$ \\
\hline 9 & Mălina TD & 83 & 80 & 103,8 & 3,05 & $* *$ \\
\hline 10 & Dekabig & 69 & 80 & 86,2 & $-11,8$ & 000 \\
\hline 11 & Asgrow & 70 & 80 & 87,9 & $-9,70$ & 000 \\
\hline 12 & Condor & 89 & 80 & 110,2 & 8,17 & $* * *$ \\
\hline 13 & Balkan & 72 & 80 & 89,0 & $-8,83$ & 000 \\
\hline
\end{tabular}

DL p $5 \% \quad 0,53$

DL $1 \% \quad 0,75$

DL p $0,1 \% \quad 1,06$

Tab. 4. Influence of density and distance between rows on number of branches per plant at the soybean varieties studied (Turda, 2012)

\begin{tabular}{|c|c|c|c|c|c|}
\hline Source of variance & $\begin{array}{c}\text { Number of } \\
\text { branches per } \\
\text { plant }\end{array}$ & Check & $\%$ & Difference & Significance \\
\hline \multicolumn{6}{|l|}{ Density } \\
\hline $\begin{array}{c}\text { D1 } \\
300000 \text { seeds/ha }\end{array}$ & 53 & 55 & 97,1 & $-1,58$ & - \\
\hline $\begin{array}{c}\text { D2 } \\
450000 \text { seeds/ha }\end{array}$ & 52 & 55 & 94,3 & $-3,12$ & 00 \\
\hline $\begin{array}{c}\text { D3 } \\
600000 \text { seeds/ha }\end{array}$ & 60 & 55 & 109,9 & 5,42 & $* * *$ \\
\hline $\begin{array}{c}\text { D4 } \\
750000 \text { seeds/ha }\end{array}$ & 54 & 55 & 98,7 & $-0,73$ & - \\
\hline $\begin{array}{ll}\text { L p 5\% } & 0,27 \\
\text { L p 1\% } & 0,37 \\
\text { L p 0,1\% } & 0,48\end{array}$ & & & & & \\
\hline
\end{tabular}

Distance between rows

\begin{tabular}{lrccccc}
\hline & $50 \mathrm{~cm}$ & 54 & 55 & 98,3 & $-0,94$ & 00 \\
\hline & $25 \mathrm{~cm}$ & 56 & 55 & 101,7 & 0,94 & $* *$ \\
\hline DL p 5\% & 0,55 & & & & & \\
DL p 1\% & 0,74 & & & & & \\
DL p 0,1\% & 0,96 & & & &
\end{tabular}


varieties have similar behavior in respect to different densities and row spacing.

We can notice some genotypes from the yield point of view such as Condor (2164 kg/ha), Malina TD and Dekabig both with $2113 \mathrm{~kg} / \mathrm{ha}$, Safir, Onix and Cristina TD with a yield around $2000 \mathrm{~kg} / \mathrm{ha}$
(Figure 1). The influence of density on yield was significantly positiv in the case of D3 (600 000 seeds/ha) with $2164 \mathrm{~kg} / \mathrm{ha}, 12 \%$ more the the average yield obtained in the conditions of the year 2012 (Tabel 8).

Tab. 5. Number of branches per plant of the soybean varieties studied (Turda, 2012)

\begin{tabular}{ccccccc}
\hline No. & Variety & Average & Check & $\%$ & Difference & Significance \\
\hline 1 & Diamant & 56 & 55 & 103,1 & 1,70 & - \\
\hline 2 & Perla & 61 & 55 & 112,3 & 6,70 & $* * *$ \\
\hline 3 & Safir & 48 & 55 & 88,3 & $-6,42$ & 00 \\
\hline 4 & Eugen & 67 & 55 & 123,2 & 12,70 & $* * *$ \\
\hline 5 & Onix & 55 & 55 & 99,8 & $-0,11$ & - \\
\hline 6 & Felix & 61 & 55 & 112,0 & 6,58 & $* * *$ \\
\hline 7 & Darina TD & 52 & 55 & 94,5 & $-2,99$ & - \\
\hline 8 & Cristina TD & 51 & 55 & 93,4 & $-3,61$ & 0 \\
\hline 9 & Mălina TD & 50 & 55 & 90,9 & $-4,99$ & 00 \\
\hline 10 & Dekabig & 51 & 55 & 93,3 & $-3,67$ & 0 \\
\hline 11 & Asgrow & 51 & 55 & 93,3 & $-3,67$ & 0 \\
\hline 12 & Condor & 56 & 55 & 102,9 & 1,58 & - \\
\hline 13 & Balkan & 51 & 55 & 93,1 & $-3,80$ & 0 \\
DL p 5 & 3,23 & & & & \\
DL p 1\% & 43 & & & & & \\
DL p 0,1\% & 6,40 & & & & &
\end{tabular}

Tab. 6. Influence of density and distance between rows grains weight per plant at the soybean varieties studied (Turda, 2012)

\begin{tabular}{|c|c|c|c|c|c|}
\hline Source of variance & $\begin{array}{c}\text { Grains weight per } \\
\text { plant } \\
\text { (gr) }\end{array}$ & Check & $\%$ & Difference & Significance \\
\hline \multicolumn{6}{|l|}{ Density } \\
\hline $\begin{array}{c}\text { D1 } \\
300000 \text { seeds } / \mathrm{ha}\end{array}$ & 18,4 & 18,7 & 98,3 & $-0,31$ & 00 \\
\hline $\begin{array}{c}\text { D2 } \\
450000 \text { seeds } / \text { ha }\end{array}$ & 18,2 & 18,7 & 97,3 & $-0,51$ & 000 \\
\hline $\begin{array}{c}\text { D3 } \\
600000 \text { seeds } / \text { ha }\end{array}$ & 19,8 & 18,7 & 105,5 & 1,03 & $* * *$ \\
\hline $\begin{array}{c}\text { D4 } \\
750000 \text { seeds/ha }\end{array}$ & 18,5 & 18,7 & 98,9 & $-0,20$ & 00 \\
\hline $\begin{array}{ll}\text { DL p 5\% } & 0,07 \\
\text { DL p 1\% } & 0,09 \\
\text { DL p 0,1\% } & 0,12 \\
\end{array}$ & & & & & \\
\hline \multicolumn{6}{|l|}{ Distance between rows } \\
\hline $50 \mathrm{~cm}$ & 18,4 & 18,7 & 98,4 & $-0,29$ & 000 \\
\hline $25 \mathrm{~cm}$ & 19,0 & 18,7 & 101,6 & 0,29 & $* * *$ \\
\hline
\end{tabular}

$\begin{array}{ll}\text { DL p 5\% } & 0,05 \\ \text { DL p 1\% } & 0,06 \\ \text { DL p 0,1\% } & 0,08\end{array}$


Tab. 7. Grains weight per plant at the soybean varieties studied (Turda, 2012)

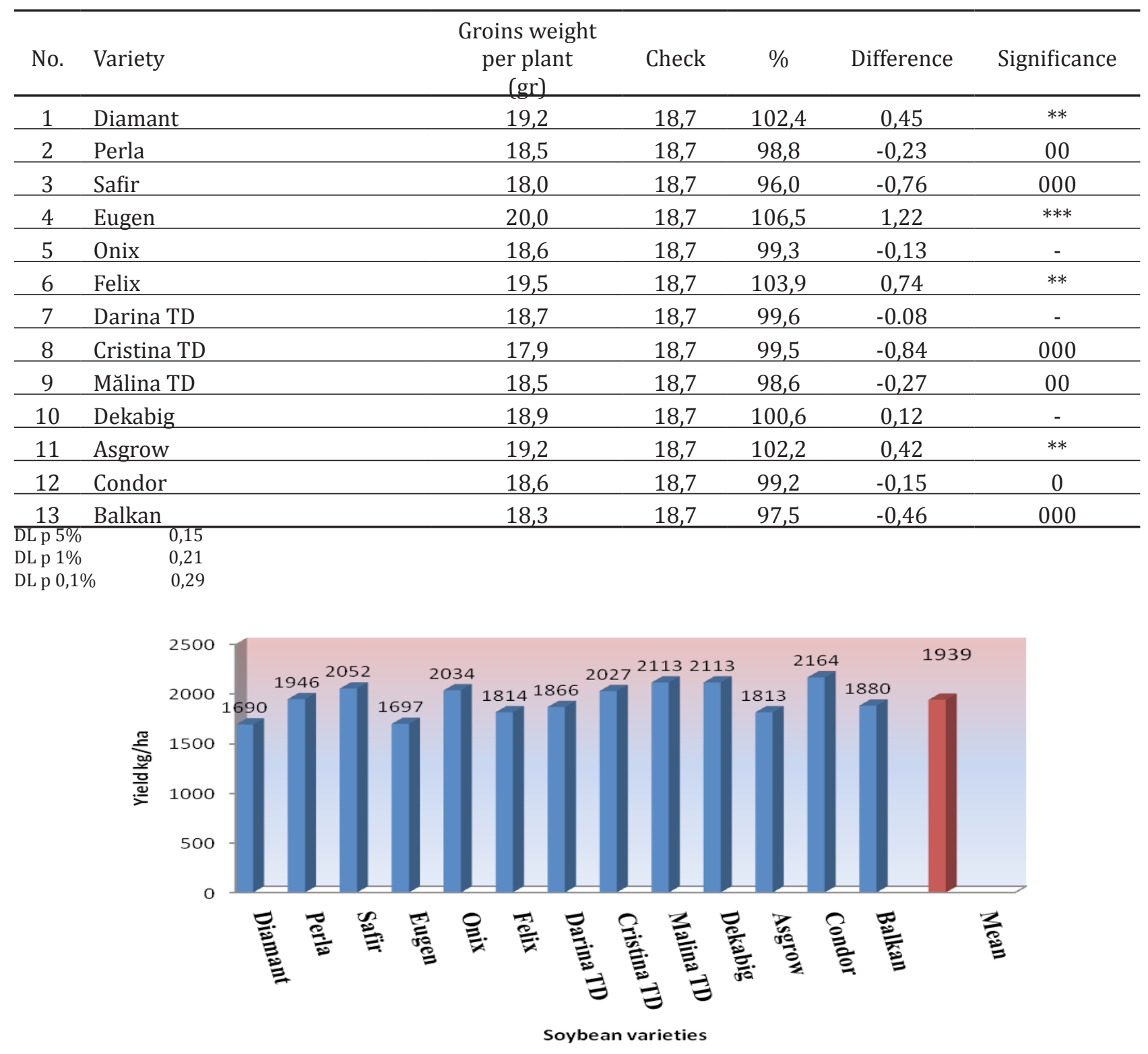

Fig. 1. Soybean varieties yield, Turda, 2012

Tab. 8. The influence of density on yield (Turda, 2012)

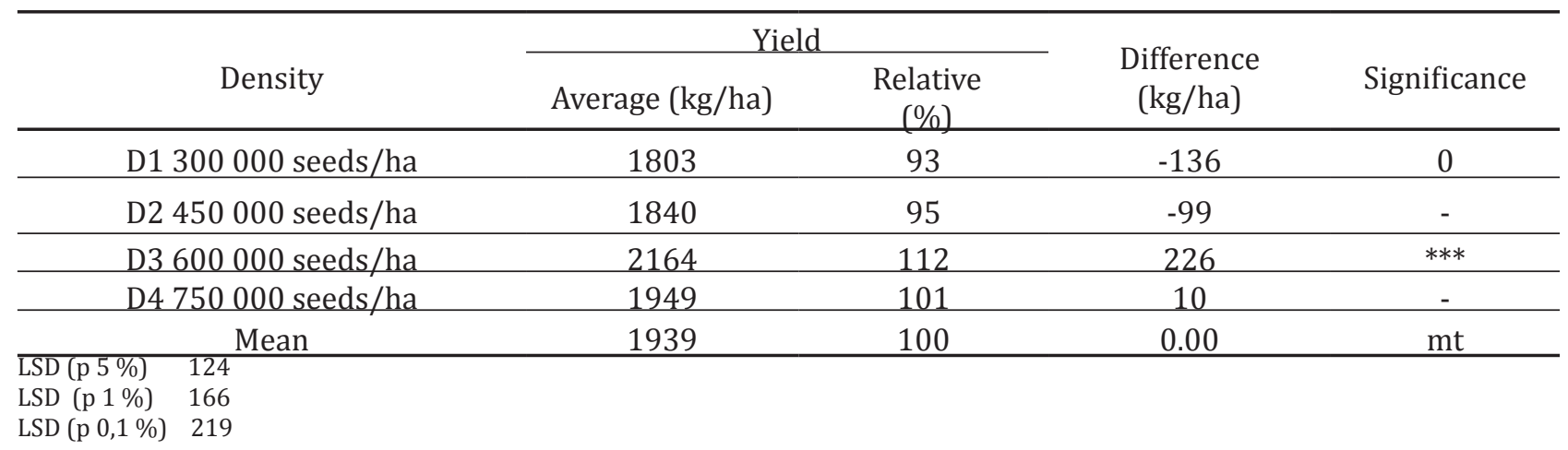




\section{CONCLUSIONS}

These results improve the understanding of correlations between different densities and soybean yield and yield components, also the response of the genotype to different interplant competition.

Soybean yield elements obtained at different plant density were determined by the yield elements and in this case we focus on the: plant height, number of branches per plant, grains weight per plant and also on the yield. The best results were obtained in the case of the characters studied at the 600000 seeds / ha density and 25 $\mathrm{cm}$ distance between rows.

We can notice some genotypes from the yield point of view such as Condor (2164 kg/ha), Malina TD and Dekabig both with $2113 \mathrm{~kg} / \mathrm{ha}$, Safir, Onix and Cristina TD with a yield around $2000 \mathrm{~kg} / \mathrm{ha}$.

\section{REFERENCES}

1. Ball RA, Purcell LC, Vories ED (2000). Crop Sci. 40:10701078.

2. Bilal Ahmad L, Badrul H, Amarjeet S, Haq SA, Sofi NR (2009). ARPN Journal of Agricultural and Biological Science 4(2):19-25.

3. Muresanu E, Marginean R (2011). Soiuri de soia create la S.C.D.A. Turda pentru Campia Transilvaniei. Agricultura Transilvana,Cultura plantelor de camp 4:56-59.

4. Muresanu E, Samartinean A, Legman V, Trifu I (2003). Onix - early soybean cultivar with qualitative traits. Romanian Agricultural Reasearch 19-20.

5. Perkins E (1995). Composition of soybeans and soybean products. Practical Handbook of Soybean Processing and Utilization, Erickson, E.R., Ed., AOCS Press, Champaign, IL. 